\title{
Liquid and plastic limits of clays by cone method
}

\author{
Binu Sharma ${ }^{1 *}\left(\mathbb{0}\right.$ and A. Sridharan ${ }^{2}$
}

*Correspondence:

binusharma78@gmail.com

${ }^{1}$ Department of Civil

Engineering, Assam

Engineering College,

Guwahati, Assam, India

Full list of author information

is available at the end of the

article

\begin{abstract}
Undrained shear strength of a soil at the liquid limit water content can be considered to be around $1.7 \mathrm{kPa}$ according to several researchers. Plasticity index of soils has been defined by one school of thought as a range of water content producing a 100-fold variation in their undrained shear strength. This has led to the redefinition of the plastic limit as the water content at which undrained shear strength is $170 \mathrm{kPa}$. The undrained shear strength-water content relationship has been found to be linear in the log-log plot for a wide range of water contents beginning from around the plastic limit to near the liquid limit. Normalization of undrained shear strength — water content relationship in a log-log plot has led to the conclusion that the water content at the liquid limit and at the plastic limit, obtained by cone penetration, could also be uniquely related. This contradicts the original understanding of Atterberg limits, namely liquid and plastic limits which are two independent parameter not related at all. It is more suitable to call this value of plastic limit from cone method as $\mathrm{PL}_{100}$ to differentiate it from Casagrande's plastic limit.
\end{abstract}

Keywords: Liquid limit, Plastic limit, Fall cone, Shear strength

\section{Introduction}

Undrained shear strength of a soil from water content around the liquid limit to water content around the plastic limit can be determined by the fall cone test. Determination of liquid limit by the fall cone test is based on the premise that soil assumes a unique state at the liquid limit yielding a unique shear strength. Many research workers have attempted to show that this unique shear strength at the liquid limit bears a definite relationship with that at the plastic limit $[2,8,13,16,25,26]$. If undrained shear strength at liquid and at the plastic limit are related then it is brought out that the liquid limit and the plastic limit could also be uniquely related.

According to several researchers $([10,12,15,23,26]$ to name a few), undrained shear strength at the liquid limit water content can be considered to be unique (without much loss of accuracy) for all soils. These researchers have shown that shearing strength of fine grained soils at the liquid limit falls within a narrow range of about 1.7-2.0 kPa. Mitchell [11], has reported equal undrained shear strength of about 1.7 to $2.0 \mathrm{kPa}$ at liquid limit water content and has mainly attributed this to the same average adsorbed water layer thickness on all particle surfaces at the liquid limit of the soil. Skempton and Northey 
[18], reported the value of shear strength at the liquid limit of four soils with very different values of plasticity index to range from 0.7 to $1.75 \mathrm{kPa}$.

Norman [14], reported that the shear strength at liquid limit water content ranges from 0.8 to $1.6 \mathrm{kPa}$ for B.S. Standard [3] rubber base Casagrande's apparatus (percussion cup) and 1.1-2.3 kPa for ASTM Standard [1] rubber base Casagrande's apparatus. Skopek and Ter-stepanian [19], have reported shear strength values in the range of 1 and $3 \mathrm{kPa}$ at the liquid limit water content in the percussion cup method. Wroth and Wood [26], adopted a mean value of $1.7 \mathrm{kPa}$ as the best estimate of undrained shear strength of a remolded soil at its liquid limit. Thus one can see that the shear strength at liquid limit varies from 0.7 to $3 \mathrm{kPa}$ but a mean value of $1.7 \mathrm{kPa}$ is widely accepted.

Data of four soil samples from Skempton and Northey [18], show that the undrained shear strength at the plastic limit is about 100 times that at the liquid limit. Based on this data, [26] have redefined plastic limit in terms of strength as that water content that gives a 100-fold increase in shear strength over that at the liquid limit. The concept that plasticity index of soils can be defined as a range of water contents producing a 100-fold variation in undrained shear strength has been brought out with the help of a large number of tests on soils of diverse nature by Sharma and Bora [16]. Attempts have also been made to determine plastic limit of soils, through the cone penetration method using this concept $[2,8,17,22,26]$.

If the soil assumes a unique state at the liquid limit yielding a unique shear strength and that this shear strength bears a definite relationship with that at the plastic limit, then it is brought out in this technical note that the water content at the liquid limit and at the plastic limit could also be uniquely related.

The plastic limit test (thread rolling method as devised by Atterberg) has become one of the standard test in soil engineering practice. According to Sridharan and Prakash [21], and Haigh [5], the two liquid limit test methods (cup and cone methods) measure different physical quantities. Cup method gives higher values of LL compared to cone method when the liquid limit is larger; whereas cone method gives higher values than cup method at lower liquid limits. This is primarily because of the controlling mechanisms involved in mobilisation of shearing resistance, primarily viscous resistance with soil of higher liquid limit and mobilisation of frictional resistance for soils at lower liquid limits [21]. According to Sridharan and Prakash [20], the cone penetration method is a measure of the undrained cohesion or undrained frictional resistance of the soil or both. Liquid limit and plastic limit determined by the cone penetration method conceptually do not represent the soil plasticity characteristics because they also represent undrained friction. Recently Haigh et al. [6] has brought out that the plastic limit is a measure of soil brittleness and does not correspond to fixed soil strength and that the plastic limit by fall cone method is not the plastic limit described by Atterberg.

In this work it is found more suitable to call plastic limit by fall cone method as $\mathrm{PL}_{100}$ to differentiate it from Casagrande's plastic limit. Hence plastic limit by the cone penetration test obtained by redefining plastic limit in terms of strength as that water content that gives a 100-fold increase in shear strength over that at the liquid limit will henceforth in this study be called $\mathrm{PL}_{100}$. For the present work a mean value of $1.7 \mathrm{kPa}$ as the shear strength at the liquid limit and $170 \mathrm{kPa}$ as the shear strength at the plastic limit $\left(\mathrm{PL}_{100}\right)$, has been adopted. 


\section{Method}

Hansbo [7], presented the theory of the fall cone test. Hansbo [7], expressed the relationship between cone penetration $(h)$ and undrained shear strength $\left(\mathrm{c}_{\mathrm{u}}\right)$ for different cone angles and weights as follows:

$$
\mathrm{c}_{\mathrm{u}}=\mathrm{KQ} / \mathrm{h}^{2}
$$

where $\mathrm{Q}=$ weight of the cone; $\mathrm{h}=$ depth of penetration of the cone into the soil; and $\mathrm{K}$ $=$ a constant, the value of which depends solely on cone angle $\beta$, for remolded soil. Equation (1) shows that the undrained shear strength is inversely proportional to the square of the depth of penetration. The $K$ value for remolded soil for the $0.59 \mathrm{~N}-60^{\circ}$ cone is 0.3 according to Hansbo [7]. According to Sharma and Bora [16], the $K$ value for the $30^{\circ}$ cone is 0.82 which was obtained after calibration of the cone by carrying out unconfined compression test. The fall cone using Eq. (1) can be used to measure the shear strength of soils at a range of water contents between liquid and plastic limits. However the undrained shear strengths obtained from using Eq. (1) are remoulded soil strengths and do not account for soil structure, fabric and overconsolidation level in the soil.

The liquid limit of the soils for this study was determined by the $0.59 \mathrm{~N}-60^{\circ}$ cone. Taking undrained shear strength at the liquid limit as $1.7 \mathrm{kPa}$, the depth of penetration $\mathrm{h}$, from Eq. (1) comes out to be $10.2 \mathrm{~mm}$. Plastic limit $\left(\mathrm{PL}_{100}\right)$, of the soils were determined by taking undrained shear strength at plastic limit as 100 times that at liquid limit, i.e., $170 \mathrm{kPa} . \mathrm{PL}_{100}$ of the soils was determined by using the $3.92 \mathrm{~N}-30^{\circ}$ cone. The depth of penetration h, from Eq. (1) for the above cone to obtain $\mathrm{PL}_{100}$ comes out to be $4.4 \mathrm{~mm}$.

For determining undrained shear strength from very soft consistencies around the liquid limit to stiff consistencies around the plastic limit, a single consistent method (the Swedish fall cone method) was used for the present study. Cones of $0.59 \mathrm{~N}-60^{\circ}$ cone angle, $0.98 \mathrm{~N}-30^{\circ}$ cone angle and $3.92 \mathrm{~N}-30^{\circ}$ cone angle have been used. The $0.59 \mathrm{~N}-60^{\circ}$ cone was used for the investigation of soft clays and the $0.98 \mathrm{~N}-30^{\circ}$ cone and $3.92 \mathrm{~N}-30^{\circ}$ cone were used for the investigation of medium and stiff clays respectively. The undrained shear strengths of the soil were determined, using the cone penetration data, from Eq. (1).

\section{Results and discussion}

The undrained shear strengths of 43 inorganic soil samples were determined by the Swedish fall cone test, the liquid limit of which varied from 33.8 to $82 \%$. The physical properties of the 43 inorganic soil samples are shown in Table 1. Plastic limit values as determined by the thread rolling method had also been incorporated in the Table 1.

Wroth and Wood [26], and Belvisco et al. [2], suggested that the logarithmic depth of penetration against water content relationship is linear between the liquid limit and the plastic limit. However Karlsson [9], Wood [24], and Harison [8], suggested the relationship to be highly nonlinear. Feng [4], also showed that the semi-logarithmic depth of cone penetration, $\mathrm{d}$ versus water content, $\mathrm{w}$ relationship is nonlinear and proposed a linear $\log d-\log w$ plot.

Sharma and Bora [16], showed that log of water content versus log of undrained shear strength is linear for soil with liquid limit less than $100 \%$. Whereas for soils with higher 
Table 1 Physical properties of the soils tested

\begin{tabular}{|c|c|c|c|c|c|c|c|}
\hline SI. no. & Site location & $\begin{array}{l}\text { Liquid } \\
\text { limit } w_{L} \\
(\%)\end{array}$ & $\begin{array}{l}\text { Plastic } \\
\text { limit } \mathrm{w}_{\mathrm{p}} \\
(\%) \\
\text { Thread } \\
\text { rolling } \\
\text { method }\end{array}$ & $\begin{array}{l}\text { Plastic } \\
\text { limit } w_{p} \\
(\%) \\
\text { Fall cone } \\
\text { method }\end{array}$ & $\begin{array}{l}\text { Plasticity } \\
\text { index P.I. } \\
(\%)\end{array}$ & $\begin{array}{l}\text { Specific } \\
\text { gravity } \\
\mathbf{G}_{s}\end{array}$ & $\begin{array}{l}\text { I.S. classification } \\
\text { (I.S.: 1948-1970) }\end{array}$ \\
\hline 1. & V.I.P. & 38.5 & 18.5 & 17 & 21.5 & 2.63 & $\mathrm{Cl}$ \\
\hline 2. & $\begin{array}{l}\text { Numaligarh- } \\
\text { B.H.-18.5 m }\end{array}$ & 56 & 23 & 24.2 & 31.8 & 2.69 & $\mathrm{CH}$ \\
\hline 3. & Noonmati Sample-2 & 69 & 25.7 & 24 & 45 & 2.72 & $\mathrm{CH}$ \\
\hline 4. & Deepar Beel & 46 & 17 & 15.5 & 30.5 & 2.57 & $\mathrm{Cl}$ \\
\hline 5. & A.E.C. Sample-3 & 61 & 24 & 22.5 & 38.5 & 2.68 & $\mathrm{CH}$ \\
\hline 6. & Ganeshguri & 37.2 & 14.2 & 15 & 22.2 & 2.59 & $\mathrm{Cl}$ \\
\hline 7. & Bentonite-I & 52 & 22.8 & 19.8 & 32.2 & 2.71 & $\mathrm{CH}$ \\
\hline 8. & Kaolinite-I & 56 & 28.4 & 27 & 29 & 2.66 & $\mathrm{CH}$ \\
\hline 9. & Gauhati University & 38 & 16.5 & 14.6 & 23.4 & 2.7 & $\mathrm{Cl}$ \\
\hline 10. & Amingaon & 54 & 23 & 22 & 32 & 2.69 & $\mathrm{CH}$ \\
\hline 11. & Sonapur & 66 & 23.2 & 24 & 42. & 2.71 & $\mathrm{CH}$ \\
\hline 12. & A.E.C. Sample-1 & 47 & 19.2 & 20.6 & 26.4 & 2.64 & $\mathrm{Cl}$ \\
\hline 13. & Silchar & 58 & 24 & 25.8 & 32.2 & 2.71 & $\mathrm{CH}$ \\
\hline 14. & Boragaon Sample-1 & 72.5 & 28 & 29 & 43.5 & 2.72 & $\mathrm{CH}$ \\
\hline 15. & Vijaynagar & 39 & 19.2 & 18.5 & 20.5 & 2.69 & $\mathrm{Cl}$ \\
\hline 16. & Numaligarh M.K.-2 & 52 & 23 & 21.5 & 30.5 & 2.62 & $\mathrm{CH}$ \\
\hline 17. & I.I.T.B.H.-I-5.7 m & 60 & 25.5 & 24.2 & 35.8 & 2.71 & $\mathrm{CH}$ \\
\hline 18. & Adabari Sample & 39.5 & 17.8 & 16.5 & 23 & 2.68 & $\mathrm{Cl}$ \\
\hline 19. & $\begin{array}{l}\text { I.I.T. (Hostel) Black } \\
\text { Soil }\end{array}$ & 59.2 & 25 & 23 & 36.2 & 2.53 & $\mathrm{CH}$ \\
\hline 20. & $\begin{array}{l}\text { Noonmati Forest } \\
\text { Gate }\end{array}$ & 77 & 31 & 28 & 49 & 2.68 & $\mathrm{CH}$ \\
\hline 21. & I.I.T.-16 (B.H.-2.5 m) & 38 & 16.5 & 14.3 & 23.7 & 2.6 & $\mathrm{Cl}$ \\
\hline 22. & Kaolinite-II & 60 & 25.3 & 25 & 35 & 2.66 & $\mathrm{CH}$ \\
\hline 23. & I.IT. B.H.-I-2.7 m & 68 & 33 & 32 & 36 & 2.66 & $\mathrm{CH}$ \\
\hline 24. & $\begin{array}{l}\text { Numaligarh Market- } \\
\text { ing Terminal-3 }\end{array}$ & 42 & 20.5 & 20 & 22 & 2.65 & $\mathrm{Cl}$ \\
\hline 25. & I.IT. B.H.-I-6 m & 58 & 21 & 22 & 36 & 2.73 & $\mathrm{CH}$ \\
\hline 26. & Numaligarh B.H.-25 & 67.5 & 26.7 & 28 & 39.5 & 2.7 & $\mathrm{CH}$ \\
\hline 27. & $\begin{array}{l}\text { Down Town Hospi- } \\
\text { tal Site-I }\end{array}$ & 44 & 18 & 16 & 28 & 2.7 & $\mathrm{Cl}$ \\
\hline 28. & Ajara & 52.5 & $21 . .5$ & 21 & 31.5 & 2.71 & $\mathrm{CH}$ \\
\hline 29. & Boragaon Sample-2 & 77 & 30.2 & 29.5 & 47.5 & 2.74 & $\mathrm{CH}$ \\
\hline 30. & Bansar & 33.8 & 17.5 & 16 & 17.8 & 2.68 & $\mathrm{CL}$ \\
\hline 31. & KC trunk sample & 52 & 21 & 19.3 & 32.7 & 2.71 & $\mathrm{CH}$ \\
\hline 32. & $\begin{array}{l}\text { Numaligarh Market- } \\
\text { ing Terminal-1 }\end{array}$ & 60 & 22.8 & 23 & 37 & 2.68 & $\mathrm{CH}$ \\
\hline 33. & Boragaon Sample-3 & 75 & 38 & 35 & 40 & 2.72 & $\mathrm{CH}$ \\
\hline 34. & A.E.C. Hostel-3 & 46 & 17.5 & 16.2 & 29.8 & 2.65 & $\mathrm{Cl}$ \\
\hline 35. & Khanapara & 68 & 25.8 & 23 & 45 & 2.68 & $\mathrm{CH}$ \\
\hline 36. & I.I.T. (B.H.-2) $2.5 \mathrm{~m}$ & 53 & 18.3 & 19 & 34 & 2.7 & $\mathrm{CH}$ \\
\hline 37. & $\begin{array}{l}\text { Numaligarh B.H.- } \\
21-8 \mathrm{~m}\end{array}$ & 57 & 22.4 & 24 & 33 & 2.68 & $\mathrm{CH}$ \\
\hline 38. & Hajo & 53.8 & 19 & 20.1 & 33.7 & 2.62 & $\mathrm{CH}$ \\
\hline 39. & Numaligarh B.H.-24 & 59 & 24.9 & 25 & 34 & 2.7 & $\mathrm{CH}$ \\
\hline 40. & $\begin{array}{l}\text { Numaligarh B.H.- } \\
15-5 \mathrm{~m}\end{array}$ & 82 & 30.8 & 32.8 & 49.2 & 2.7 & $\mathrm{CH}$ \\
\hline
\end{tabular}


Table 1 (continued)

\begin{tabular}{|c|c|c|c|c|c|c|c|}
\hline SI. no. & Site location & $\begin{array}{l}\text { Liquid } \\
\operatorname{limit}_{\mathrm{L}} \\
(\%)\end{array}$ & $\begin{array}{l}\text { Plastic } \\
\text { limit } w_{p} \\
(\%) \\
\text { Thread } \\
\text { rolling } \\
\text { method }\end{array}$ & $\begin{array}{l}\text { Plastic } \\
\text { limit } w_{p} \\
(\%) \\
\text { Fall cone } \\
\text { method }\end{array}$ & $\begin{array}{l}\text { Plasticity } \\
\text { index P.I. } \\
\text { (\%) }\end{array}$ & $\begin{array}{l}\text { Specific } \\
\text { gravity } \\
\mathbf{G}_{s}\end{array}$ & $\begin{array}{l}\text { I.S. classification } \\
\text { (I.S.: 1948-1970) }\end{array}$ \\
\hline 41. & Mirza & 38 & 16 & 14.5 & 23.5 & 2.59 & $\mathrm{Cl}$ \\
\hline 42. & Chaygaon & 42 & 16.5 & 16 & 26 & 2.6 & $\mathrm{Cl}$ \\
\hline 43. & Jorabat & 68 & 20 & 19.6 & 48.4 & 2.69 & $\mathrm{CH}$ \\
\hline
\end{tabular}

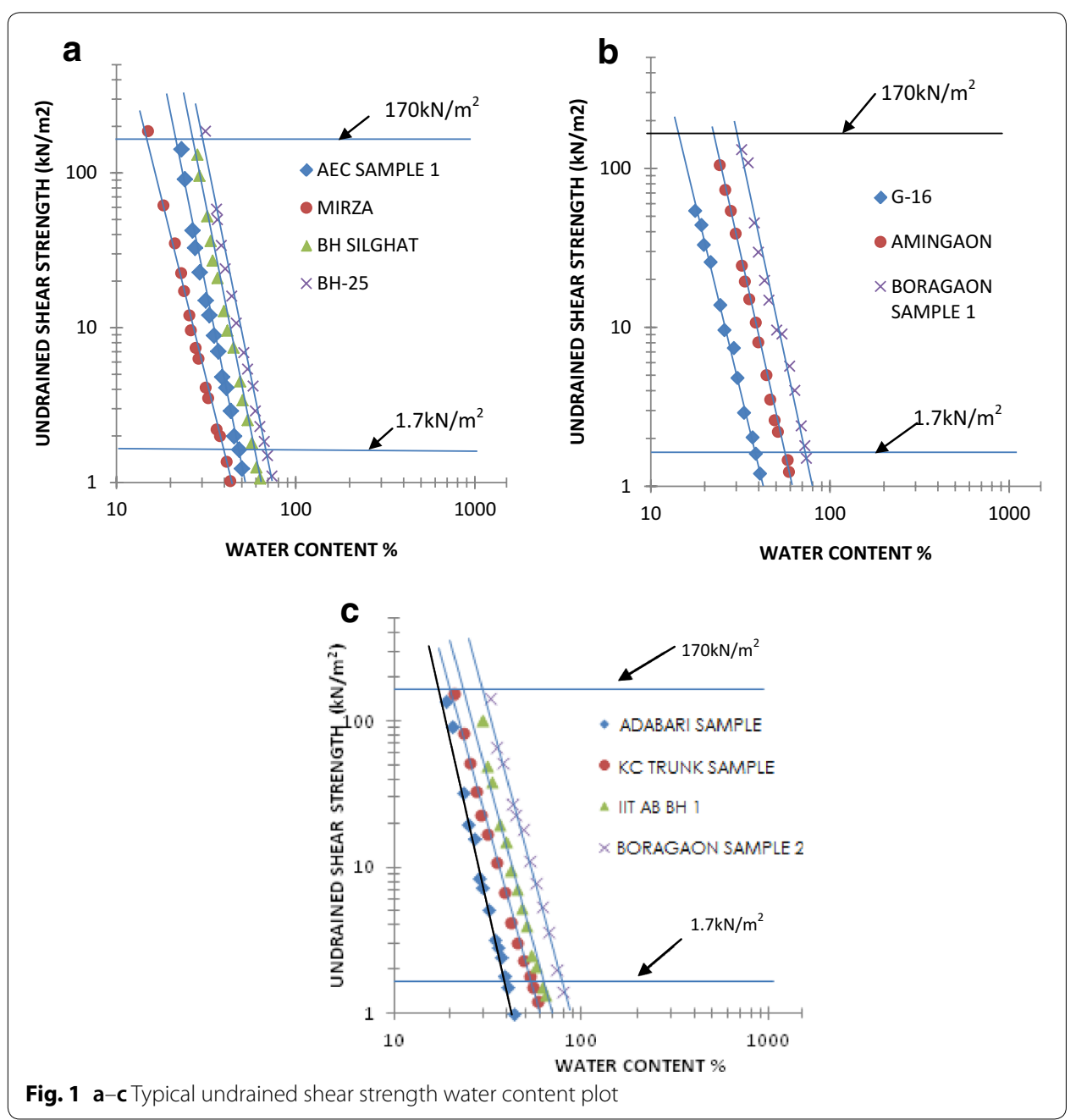

liquid limits a bilinear relationship was obtained. The straight line relationship was seen to exist from water content around the liquid limit to water content around the plastic limit of the soils tested. Youssef et al. [27], also showed that a straight line relation existed between water content and undrained shear strength in a log-log plot but they had data only near the liquid limit of the soils.

When water content, $\mathrm{w}$ was plotted against undrained shear strength, $\mathrm{c}_{\mathrm{u}}$, on a $\log -\log$ scale, a straight line for each soil sample was obtained. Figure 1a-c show typical results 
for the 43 samples tested. Vane shear test was also carried out to determine undrained shear strength at different water contents. Vane shear test results are incorporated together with the cone penetration test results in Fig. 2 wherein it is seen that there is good agreement of the cone penetration test results with those of the vane shear test results. This example is typical of all such results obtained. The linear $\log w-\log c_{u}$ model is expressed as follows

$$
\log c_{u}=\log c+m \log w .
$$

An attempt is made in the following paragraph to generalize this behaviour of the soils through normalization. The straight line relationship of undrained shear strength and water content in a log-log plot of the 43 samples have been redrawn normalising the undrained shear strength at any water content with $1.7 \mathrm{kPa}$ i.e. the undrained shear strength at liquid limit on the $\mathrm{Y}$ axis and normalizing the corresponding water content with the water content at liquid limit of the soils on the $\mathrm{X}$ axis. After normalization, all the soil test results plot in a narrow band, which is shown in Fig. 3, and which can be fitted with an equation of the form

$$
\log \left(\mathrm{c}_{\mathrm{u}} / 1.7\right)=\log (1.04)-4.9 \log (\mathrm{w} / \mathrm{LL})
$$

with a correlation coefficient of $0.95, c_{u}=$ undrained shear strength at any water content, $\mathrm{w}=$ water content, $\mathrm{LL}=$ liquid limit water content.

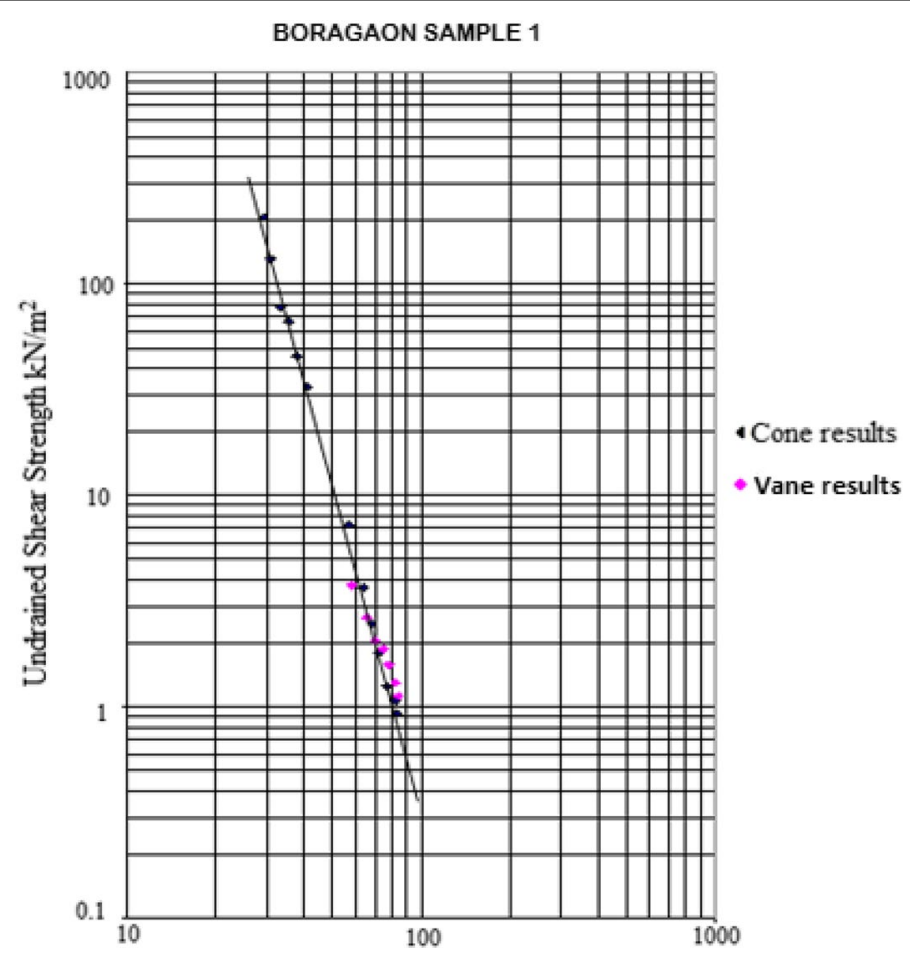

Water content $\%$

Fig. 2 Comparison of undrained shear strength results from fall cone test and vane shear test 


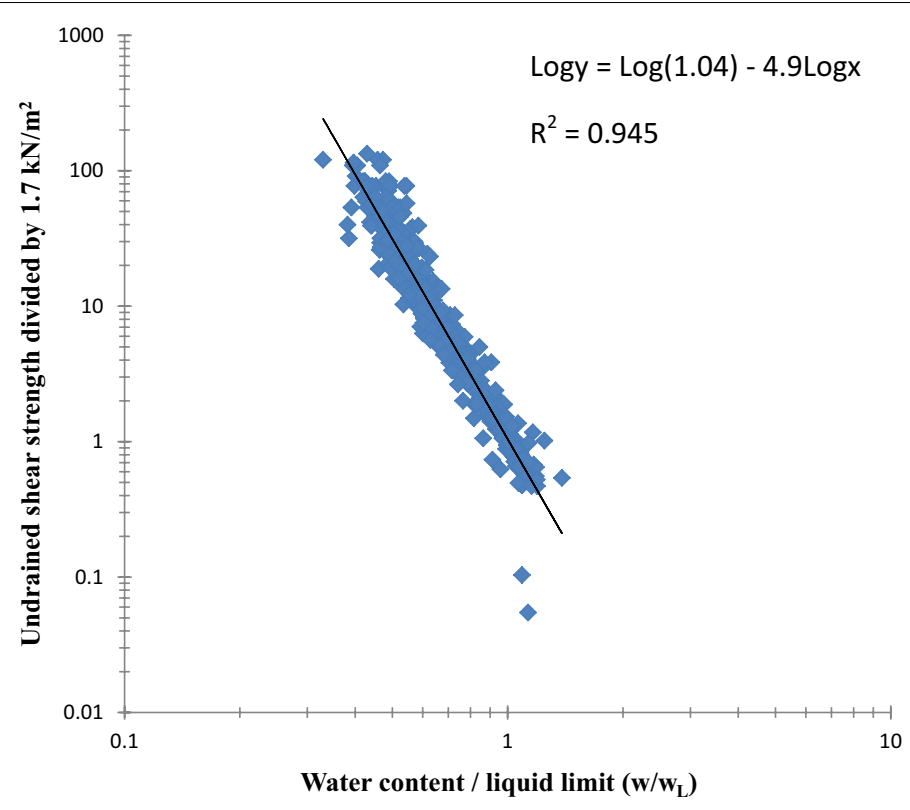

Fig. 3 Normalised plot with data of the 43 soil samples

Equation [3] can be written without loss of accuracy in the form

$$
\log \left(c_{u} / 1.7\right)=\log (1)-4.9 \log (w / L L)
$$

or

$$
\log \left(c_{\mathrm{u}} / 1.7\right)=-4.9 \log (\mathrm{w} / \mathrm{LL})
$$

The undrained shear strength of a soil at any water content can be determined by this relationship knowing only the liquid limit of the soils.

Taking undrained shear strength at the plastic limit as $170 \mathrm{kPa}$, and denoting this plastic limit as $\mathrm{PL}_{100}$, Eq (4) can be written as

$$
\log (170 / 1.7)=-4.9 \log \left(\mathrm{PL}_{100} / \mathrm{LL}\right)
$$

or

$$
\begin{aligned}
& \mathrm{PL}_{100}=0.39 \mathrm{LL} \\
& I_{p}=0.61 L L
\end{aligned}
$$

$\mathrm{I}_{\mathrm{p}}=$ plasticity index of the soils.

Equations (6) and (7) show that water content at liquid limit and water content at plastic limit, are uniquely related.

Statistical analysis of the 43 soil samples tested in this work, for the best fitting straight line produced an equation as

$$
I_{p}=0.63(L L-1.63)
$$

or

$$
I_{p}=0.63(L L-1.03)
$$


Again the same analysis for the best fitting straight line passing through the origin produced an equation as

$$
\mathrm{I}_{\mathrm{p}}=0.6 \mathrm{LL}
$$

which is exactly the same as Eq. (7).

Figure 4 shows the liquid limit and plasticity index plot on the plasticity chart with the fitted straight line (Eq. 8), with plastic limit determined by the fall cone test corresponding to an undrained shear strength of $170 \mathrm{kPa}$.

While experimental results of this investigation leads to Eq. (9), the equation obtained from the normalization of the strength results yielded Eq. (7). Both of them compare well in view of the altogether two different approaches. Figure 5 illustrates the plastic limit $\left(\mathrm{PL}_{100}\right)$, obtained from cone experiments and that from prediction of the normalised plot of strengths at different water contents by Eq. (7). In view of altogether two different methods, the results compare well.

In the above discussions, it has been brought out that if the strength at plastic limit and at liquid limit are 1.7 and $170 \mathrm{kPa}$ respectively, then experimental results indicate that both liquid limit and plastic limit are uniquely related as given in Eq. (7). This leads to the redundent of plasticity chart which is extensively used by practicing geotechnical engineers. Though the concept that undrained shear strength at liquid limit and at the plastic limit can be uniquely related which in turn leads to unique relation between liquid limit and plastic limit of the soils, this can be said to be true only when plastic limit is determined from the cone penetration test assuming a 100-fold increase in shear strength over that at the liquid limit.

\section{Conclusions}

The undrained shear strength-water content relationship has been found to be linear in a log-log plot for a range of water contents beginning from around the plastic limit to around the liquid limit for a variety of soils with liquid limits ranging from 33.8 to $82 \%$

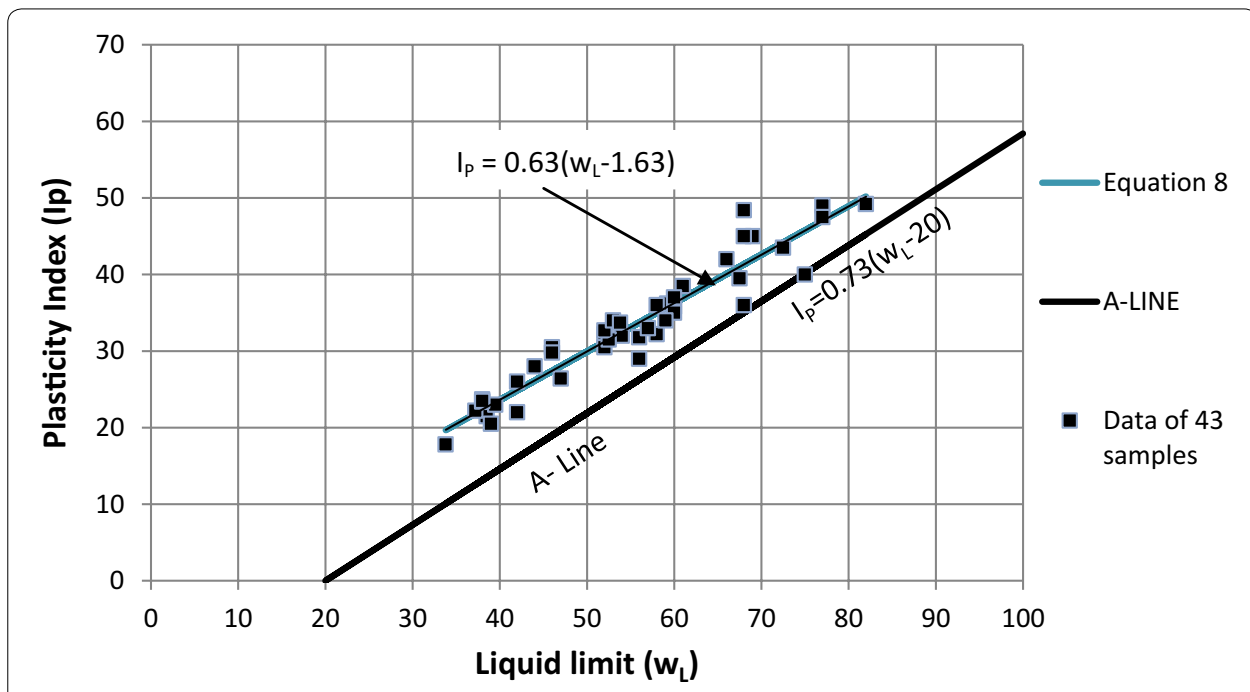

Fig. 4 Relationship between plasticity index and liquid limit with data from present work 


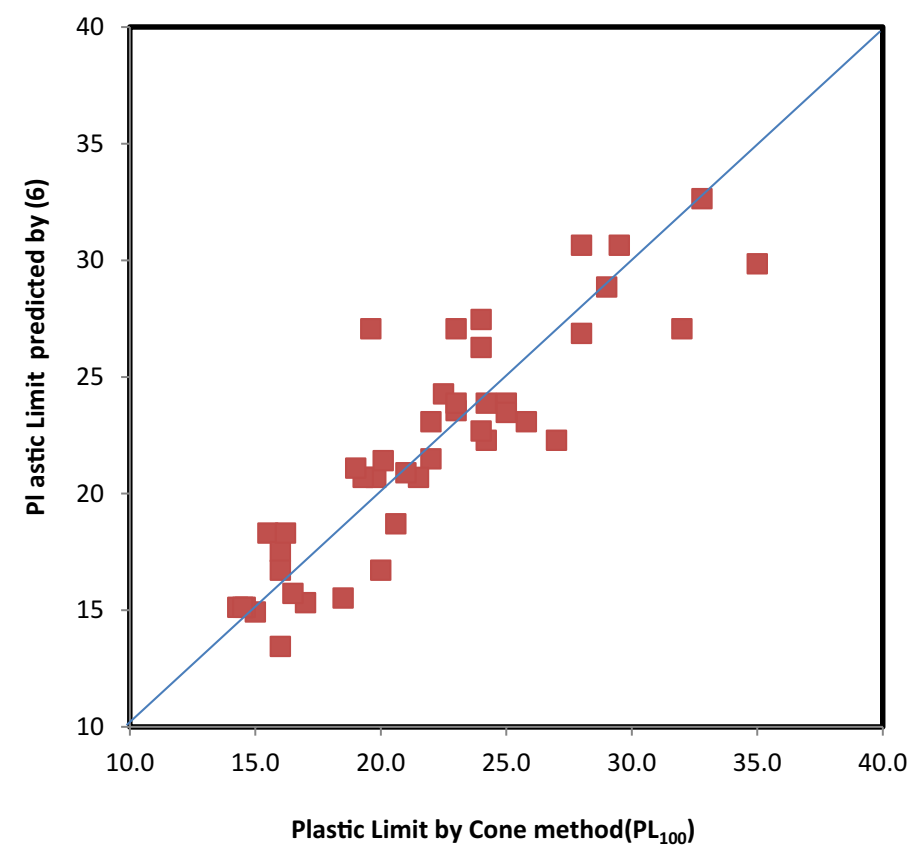

Fig. 5 Comparison of Plastic limit by cone method with plastic limit as predicted by [7]

and plastic limit by cone method ranging from 15 to $35 \%$ plotting above Casagrande A-line. Review of literature show that one can assume a unique state at the liquid limit yielding a shear strength of $1.7 \mathrm{kPa}$. Water content corresponding to an undrained shear strength of $170 \mathrm{kPa}$ is also called the plastic limit of the soil by different research workers. This plastic limit is called $\mathrm{PL}_{100}$ in this work. This has led to the finding in this investigation that the water content at the liquid limit and at the plastic limit can also be uniquely related. This leads to the contradiction what Atterberg originally envisaged leading to Casagrande plasticity chart. At best this assertion that at liquid limit yielding a unique shear strength and that this shear strength bears a definite relationship with that at the plastic limit could be valid only when plastic limits are determined by the cone penetration method by assuming undrained shear strength at plastic limit as $170 \mathrm{kN} / \mathrm{m}^{2}$. It is more suitable to call the value of plastic limit determined by the cone as $\mathrm{PL}_{100}$ to differentiate it from Casagrande's plastic limit.

Authors' contributions

BS and AS carried out the liquid and plastic limits of clays by cone method studies, participated in the sequence alignment and drafted the manuscript. All authors read and approved the final manuscript.

Author details

${ }^{1}$ Department of Civil Engineering, Assam Engineering College, Guwahati, Assam, India. ${ }^{2}$ Indian National Science Academy, New Delhi, India.

Competing interests

The authors declare that they have no competing interests.

\section{Publisher's Note}

Springer Nature remains neutral with regard to jurisdictional claims in published maps and institutional affiliations. 


\section{References}

1. ASTM D4318-98. Standard test methods for liquid limit, plastic limit, and plasticity index of soils. Annual book of ASTM standards, American Society for Testing and Materials, Philadelphia

2. Belvisco R, Clampoli S, Cotecchia V, Federico A (1985) Use of cone penetrometer to determine consistency limits. Ground Eng 18(5):21-22

3. BS 1377-2 (1990) Methods of test for soils for civil engineering purposes: classification tests. British Standards Institution, London

4. Feng TW (2000) Fall cone penetration and water content relationship of clays. Geotechnique 50(2):181-187

5. Haigh SK (2012) Mechanics of the Casagrande liquid limit test. Can Geotech 49:1015-1023

6. Haigh SK, Vardanega PJ, Boltan MD (2013) The plastic limit of clays. Geotechnique 63(6):435-440

7. Hansbo S (1957) A new approach to the determination of the shear strength of clay by the fall cone test. Swedish Geotech Institute Proc., Stockholm, pp 1-48

8. Harison JA (1988) Using the BS cone penetrometer for the determination of the plastic limit of soils. Geotechnique 38(3):433-438

9. Karlsson R (1961) Suggested improvements in the liquid limit test with reference to flow properties of remoulded clays. In: Proceeding 5th international conference on soil mechanics and foundation engineering, Paris, Vol. 1, pp $171-184$

10. Kenny TC (1963) Atterberg limits. Correspondence Geotech 13:159-162

11. Mitchell JK (2005) Fundamentals of soil behaviour. Wiley, New York

12. Nagaraj TS, Srinivasa Murthy BR, Vatsala A (1990) Prediction of soil behaviour. Development of a generalised approach. Indian Geotech J 20(4):288-306

13. Nagaraj TS, Srinivasa Murthy BR, Vatsala A (1994) Analysis and prediction of soil behaviour. Wiley Eastern Limited, India

14. Norman LEJ (1958) A comparison of values of liquid limit determined with apparatus having bases of different hardness. Geotechnique 8:79-83

15. Russel ER, Mickle JL (1970) Liquid limit values by soil moisture tension. J Soil Mech Found Div 96(3):967-989

16. Sharma B, Bora PK (2003) Plastic limit, liquid limit and undrained shear strength of soil-reappraisal. J Geotech Geoenv Eng. 129(8):774-777

17. Sharma B, Bora PK (2004) Determination of plastic limit of soils by cone penetration method. Indian Geotech J 34(4):297-312

18. Skempton AW, Northey RD (1953) The sensitivity of clays. Geotechnique 3:30-53

19. Skopeck J, Ter-Stepanian G (1975) Comparison of liquid limit values determined according to Casagrande and Vesilev. Geotechnique. 25(1):135-136

20. Sridharan A, Prakash K (1999) Mechanisms controlling the undrained shear strength behaviour of clays. Can Geotech J 36(6):1030-1038

21. Sridharan A, Prakash K (2000) Percussion and cone methods of determining the liquid limit of soils: controlling mechanisms. Geotech Test J 23(2):236-244

22. Stone KJL, Phan KD (1995) Cone penetration tests near the plastic limit. Geotechnique 45(1):155-158

23. Whyte IL (1982) Soil plasticity and strength - a new approach using extrusion. Ground Eng 15(1):16-24

24. Wood DM (1985) Index properties and consolidation history. In: Proc. 11th Int. Conf. on soil mechanics and foundation engineering, San Francisco, pp 703-706

25. Wroth CP (1979) Correlation of some engineering properties of soils. In: 2nd Int. Conf. on Boss, Imperial College, London, pp 121-132

26. Wroth CP, Wood DM (1978) The correlation of index properties with some basic engineering properties of soils. Can Geotech J 15(2):137-145

27. Youssef MS, Ramli EL, Demery M (1965) Relationship between shear strength, consolidation, liquid limit and plastic limit for remolded clays. In: Proc., 6th int. conf. on soil mechanics, Montreal, pp 126-129

\section{Submit your manuscript to a SpringerOpen ${ }^{\circ}$ journal and benefit from:}

- Convenient online submission

- Rigorous peer review

- Open access: articles freely available online

- High visibility within the field

- Retaining the copyright to your article

Submit your next manuscript at $\gg$ springeropen.com 